\title{
EVALUATION OF THE HEALTHY LIFE YEARS INDICATOR IN CONDITIONS OF EU DIGITALIZATION
}

Formulation of the problem. Digitalization is an end-to-end process that affects both the economic and social aspects of human activity. A quantitative assessment of the quality of expansion of the digital economy is one of the important scientific and practical problems. As a rule, its solution is sought purely on an economic plane. It's exist the estimate of the digital GDP percentage, the growth in the share of e-commerce, online services, the capitalization of technology companies, and the volume of cashless payments. However, the ultimate goal of digitalization is a person, the quality and expectancy of his life. Therefore, in general terms, there is a problem of assessing the impact of digitalization on a person.

Literature review. Researchers of digitalization processes consider its various aspects [1-4]. They agree on the fundamental impact of these processes on the economy and society. Particular attention is paid to the connection of the digitalization of the economy with the development of medical services [1, p.143-152; 5] and the solution of environmental problems [6]. At the same time, the assessment of the impact of digitalization on human life, which is characterized primarily by life expectancy, remains without proper attention. "Life expectancy at birth reflects the living conditions of the population and is a direct consequence of the socio-economic situation of the territory" [7, p. 61]. It should be borne in mind that modern researchers prefer the Healthy Life Years (HLY) indicator [8-10]. "Healthy Life Years (HLY) allow estimating the quality of the remaining years that a person is expected to live, in terms of being free of long-standing activity limitation" [8, p.1]. Researchers identify the following factors that affect HLY: «Air pollution - carbon dioxide emission in tons per capita; Education - fraction of population with tertiary education; GDP per capita; Material deprivation - fraction of population with 4 or more important housing items missing; Social protection expenditures to GDP; Population density; Beds in hospitals per 100000 inhabitants; Doctors per 100000 inhabitants; Alcohol consumption in liters per capita; Cigarettes - fraction of regular smokers in population; Obesity - fraction of obese inhabitants in population [10, p.185]. Thus, the problem of the influence of digitalization on the HLY indicator remains insufficiently studied Based on this, a hypothesis can be formulated that countries with a higher level of digitalization will be able to provide more HLY for their citizens and its positive dynamics.
Object of research. The EU is a unique entity, which harmoniously combines the signs of a single and universal. On the one hand, the EU includes sovereign states, and on the other, it is a single labor and capital market. The EU is actively supporting digitalization processes at the legislative level and work is underway to build a Digital Single Market. EU adopted "A Digital Agenda for Europe" [11], "A Digital Single Market Strategy for Europe" [12], "Building a European Data Economy" [13], and other regulations [14, p.122-123]. Therefore, the EU is a suitable target for testing a hypothesis.

Aim of research. Based on a review of the literature and the object of study, the aim of the study is to evaluate the state and dynamic of "Healthy Life Years" in conditions of EU digitalization.

Methods. There are various indicators for assessing the level of digitalization of countries [15-23]. The Digital Economy and Society Index (DESI) [17] the only of the considered indices is calculating specifically for the EU countries. Therefore, it was he who was chosen to assess the digitalization level of the EU member states. Healthy Life Years Index is calculated by Eurostat [24].

The Spearman's rank correlation coefficient was used as an analytical tool for evaluating the tightness of communication.

Results and discussion. Analysis of the HLY index shows that among the EU-28 has a significant difference (table). The leaders in HLY at birth for females (table, column 10) are Malta and Sweden, where this indicator is 73.4 and 71.9 years at the end of 2017. Moreover, in terms of digitalization, they occupy the 8th and 4th place. The last two positions are occupied by Slovenia and Latvia (54.6 and 52.2 years respectively). In terms of digitalization, they occupy the 16th and 19th positions.

The difference between the first and last position for HLY at birth for females (table, column 10) is 21.2 years. The median value for the sample is 61.4.

A similar situation is observed for HLY at birth for males (table, column 14), where in terms of HLY at birth the first positions are occupied by the same Malta (71.9 years) and Sweden (73.2 years). The last positions are held by Estonia ( 54.7 years) and Latvia (50.6 years).

The difference between the first and last position for HLY at birth for males (table, column 14) is 22.6 years. The median value for the sample is 60.6 . 
DESI and HLY at birth in EU countries in 2014-2017

\begin{tabular}{|c|c|c|c|c|c|c|c|c|c|c|c|c|c|}
\hline \multirow{2}{*}{ No. } & \multirow{2}{*}{ Country } & \multicolumn{4}{|c|}{ DESI } & \multicolumn{4}{|c|}{ HLY at birth (females) } & \multicolumn{4}{|c|}{ HLY at birth (males) } \\
\hline & & $14^{1}$ & 15 & 16 & 17 & 14 & 15 & 16 & 17 & 14 & 15 & 16 & 17 \\
\hline 1 & 2 & 3 & 4 & 5 & 6 & 7 & 8 & 9 & 10 & 11 & 12 & 13 & 14 \\
\hline 1 & Austria & 12 & 13 & 12 & 12 & 57,8 & 58,1 & 57,1 & 56,8 & 57,6 & 57,9 & 57 & 57,4 \\
\hline 2 & Belgium & 9 & 9 & 7 & 7 & 63.7 & 64 & 63.8 & 64.1 & 64.4 & 64.4 & 63.7 & 63.5 \\
\hline 3 & Bulgaria & 27 & 27 & 26 & 27 & 66.1 & 65 & 67.5 & 66.2 & 62 & 61.5 & 64 & 62.9 \\
\hline 4 & Croatia & 21 & 20 & 20 & 20 & 60 & 56.8 & 58.7 & 58 & 58.6 & 55.3 & 57.1 & 57.3 \\
\hline 5 & Cyprus & 23 & 23 & 21 & 22 & 66.1 & 63.4 & 68.8 & 65.8 & 65.8 & 63.1 & 67.5 & 64.7 \\
\hline 6 & Czechia & 17 & 14 & 17 & 15 & 65 & 63.7 & 64 & 62.4 & 63.4 & 62.4 & 62.7 & 60.6 \\
\hline 7 & Denmark & 2 & 1 & 1 & 1 & 61.4 & 57.6 & 60.3 & 59.7 & 60.3 & 60.4 & 60.3 & 59.8 \\
\hline 8 & Estonia & 7 & 7 & 9 & 9 & 57.1 & 56.2 & 59 & 57.2 & 53.2 & 53.8 & 54.4 & 54.7 \\
\hline 9 & Finland & 3 & 2 & 2 & 2 & 57.5 & 56.3 & 57 & 56.4 & 58.7 & 59.4 & 59.1 & 58.3 \\
\hline 10 & France & 14 & 15 & 15 & 14 & 64.2 & 64.6 & 64.1 & 64.9 & 63.4 & 62.6 & 62.6 & 62.5 \\
\hline 11 & Germany & 10 & 11 & 11 & 11 & 56.5 & 67.5 & 67.3 & 66.7 & 56.4 & 65.3 & 65.3 & 65.1 \\
\hline 12 & Greece & 26 & 26 & 27 & 26 & 64.9 & 64.1 & 64.7 & 65.1 & 64.1 & 63.9 & 63.8 & 64.4 \\
\hline 13 & Hungary & 22 & 22 & 22 & 23 & 60.6 & 60.1 & 60.2 & 60.8 & 59.1 & 58.2 & 59.5 & 59.6 \\
\hline 14 & Ireland & 11 & 10 & 10 & 10 & 67.5 & 68 & 69.8 & 69.3 & 66.3 & 66.5 & 67.2 & 67.9 \\
\hline 15 & Italy & 25 & 24 & 24 & 24 & 62.3 & 62.7 & 67.2 & 66.4 & 62.5 & 62.6 & 67.6 & 66.2 \\
\hline 16 & Latvia & 19 & 19 & 19 & 19 & 55.3 & 54.1 & 54.9 & 52.2 & 51.5 & 51.8 & 52.3 & 50.6 \\
\hline 17 & Lithuania & 18 & 18 & 18 & 18 & 61.7 & 58.8 & 59.4 & 59.8 & 57.6 & 54.1 & 56.2 & 56.4 \\
\hline 18 & Luxembourg & 5 & 5 & 5 & 5 & 63.5 & 60.6 & 58.9 & 58.1 & 64 & 63.7 & 61.4 & 60.1 \\
\hline 19 & Malta & 8 & 8 & 8 & 8 & 74.5 & 74.6 & 72.4 & 73.4 & 72.3 & 72.6 & 71.1 & 71.9 \\
\hline 20 & Netherlands & 4 & 4 & 4 & 3 & 59 & 57.2 & 57.8 & 57.6 & 63.3 & 61.1 & 62.8 & 62.3 \\
\hline 21 & Poland & 24 & 25 & 25 & 25 & 62.7 & 63.2 & 64.6 & 63.5 & 59.8 & 60.1 & 61.3 & 60.6 \\
\hline 22 & Portugal & 16 & 17 & 14 & 17 & 55.4 & 55 & 57.4 & 57 & 58.4 & 58.2 & 59.9 & 60.1 \\
\hline 23 & Romania & 28 & 28 & 28 & 28 & 59.1 & 59.3 & 59 & 58.3 & 58.9 & 59 & 59.8 & 59.2 \\
\hline 24 & Slovakia & 20 & 21 & 23 & 21 & 54.6 & 55.1 & 57 & 55.6 & 55.5 & 54.8 & 56.4 & 55.6 \\
\hline 25 & Slovenia & 15 & 16 & 16 & 16 & 59.6 & 57.7 & 57.9 & 54.6 & 57.8 & 58.5 & 58.7 & 55.3 \\
\hline 26 & Spain & 13 & 12 & 13 & 13 & 65 & 64.1 & 66.5 & 69.9 & 65 & 63.9 & 65.9 & 69 \\
\hline 27 & Sweden & 1 & 3 & 3 & 4 & 72.8 & 72.2 & 73.3 & 71.9 & 73 & 73.1 & 73 & 73.2 \\
\hline 28 & UK & 6 & 6 & 6 & 6 & 64.2 & 63.3 & 63.1 & 62 & 63.3 & 63.7 & 63 & 63.3 \\
\hline
\end{tabular}

114 means 2014, 15 - 2015.

Source: compiled by the author using data of Eurostat [17; 24].

Thus, the HLY at birth statistics for women and men are not fundamentally different.

For a more detailed analysis, the EU-28 member countries were divided into 4 quartiles by digitalization level. First quartile from 1 to 7 place (Denmark, Finland, Netherlands, Sweden, Luxembourg, United Kingdom, Belgium), second quartile from 8 to 14 (Malta, Estonia, Ireland, Germany, Austria, Spain, France), third quartile from 15 to 21 (Czechia, Slovenia, Portugal, Lithuania, Latvia, Croatia, Slovakia), the fourth quartile from 22 to 28 (Cyprus, Hungary, Italy, Poland, Greece, Bulgaria, Romania). For each quartile, the mean values of HLY at birth for females and males in 2017 were calculated. The graphic image (fig. 1) of these shows the uneven distribution pattern without any distinct tendency. HLY at birth for females and males in the 1st quartile in terms of digitalization is lower than in the second (61.4 years for female and 62.93 years for male in 1st quartile and 65.46 years for female and 64.07 years for male in 2 nd quartile). A similar situation when comparing the $3 \mathrm{rd}$ and 4th quartiles.

The Spearman's rank correlation coefficient between HLY at birth (females) and DESI in 2017 is -
0.0268. The Spearman's rank correlation coefficient between HLY at birth (males) and DESI in 2017 is 0.0268 .

Thus, analytically and graphically, there is no positive relationship between the level of digitalization of countries and HLY at birth for both sex.

A separate issue is the study of the impact of digitalization on the dynamics of HLY. For 4 years (20142017), EU-28 member countries have demonstrated multidirectional dynamics. According to HLY at birth (females) in 13 countries (Germany, Spain, Italy, Ireland, Portugal, Slovakia, Poland, France, Belgium, Hungary, Greece, Bulgaria, Estonia) is positive changing. The leaders are Germany $(+10.2$ years $)$, Spain $(+4.9)$ and Italy $(+4.1)$. The average increase for these countries amounted to 2 years. However, in 15 countries (Cyprus, Romania, Sweden, Austria, Malta, Finland, Netherlands, Denmark, Lithuania, Croatia, the United Kingdom, Czechia, Latvia, Slovenia, Luxembourg) there was a decrease, which also averaged 2 years. The largest declines were recorded in Slovenia ( -5 years) and Luxembourg ( -5.4 years). 


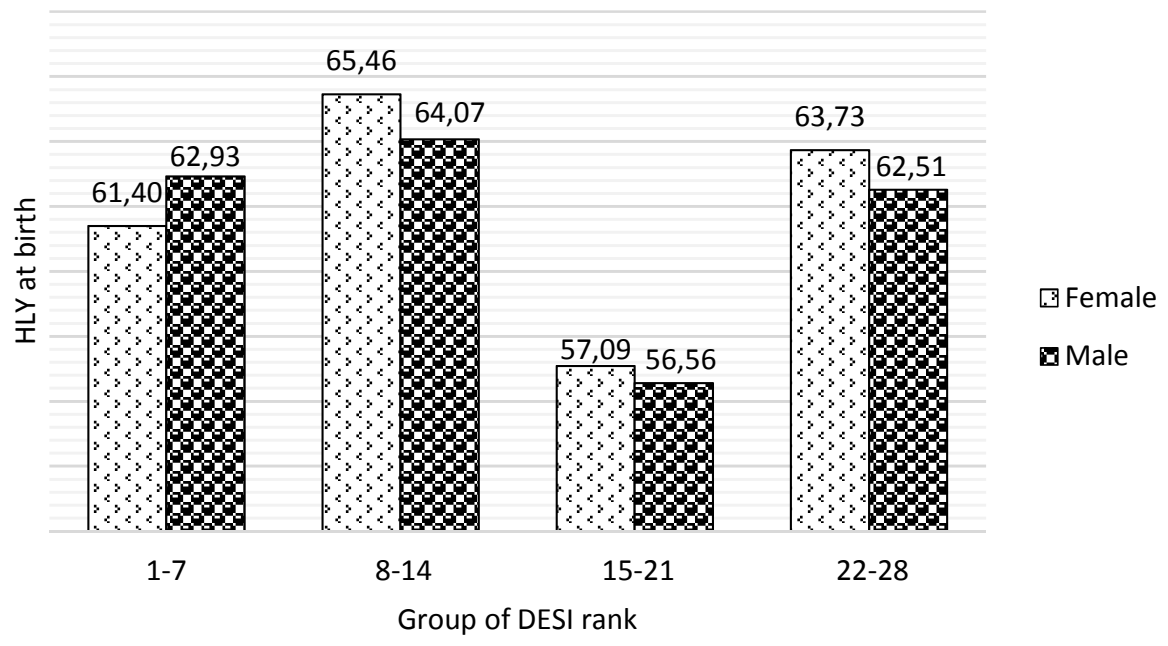

Fig. 1. HLY at birth in DESI quarters

Similarly, for HLY at birth for males. 13 countries shown growth. These are Germany, Spain, Italy, Portugal, Ireland, Estonia, Bulgaria, Poland, Hungary, Greece, Romania, Sweden, Slovakia. The average increase is 1.87 years. The leaders are the same Germany ( +8.7 years), Spain $(+4$ years) and Italy ( +3.7 years). A decrease in HLY at birth for males was recorded in 14 countries (Austria, Malta, Finland, Denmark, France, Latvia, Belgium, Netherlands, Cyprus, Lithuania, Croatia, Slovenia, Czechia, Luxembourg). The average decline is 1.3 years. Among the outsiders are Slovenia (-2.5), Czechia (-2.8), Luxembourg (-3.9). In the United Kingdom unchanged.

Thus, despite the deepening digitalization level in most EU-28 countries, there is a negative trend. It remains to explore how this dynamic is consistent with the level of digitalization. For this, the average rank for the EU-28 member countries for 2014-2017 was calculated.

All the Top 5 countries in terms of digitalization showed a negative change in the level of HLY at birth: Denmark ( -1.7 years for female; -0.5 years for male), Finland ( -1.1 years for female; -0.4 years for male), Sweden ( -0.9 years for female; +0.2 years for male), Netherlands (-1.4 years for female; -1 year for male), Luxembourg (-5.4 years for female; -3.9 years for male). For 5 countries that occupy the last positions in terms of digitalization is more positive situation: Italy ( +4.1 years for female; +3.7 years for male), Poland $(+0.8$ years for female; +0.8 years for male), Greece ( +0.2 years for female; +0.3 years for male), Bulgaria $(+0.1$ years for female; +0.9 years for male), Romania ( -0.8 years for female; +0.3 years for male).

If we analyze the quartile distribution (fig. 2), then the discrepancy between the digitalization level of the dynamics of changes in HLY at birth becomes noticeable. In the 1st quartile, according to the level of digitalization, the average decrease in HLY at birth is -1.8 years for females and -0.59 years for males. In the 2 nd quartile in terms of level of digitalization, the average increase in HLY at birth is 2.27 years for females and 1.7 years for males. In the 3 rd quartile, according to the level of digitalization, the average decrease in HLY at birth is -1.71 years for females and -0.99 years for males. In the 4th quartile in terms of digitalization, the average increase in HLY at birth is 0.61 years for females and 0.77 years for males.

The Spearman's rank correlation coefficient between the change in HLY at birth (females) in 2017 relative to 2014 and the average DESI in 2014-2017 is -0.28 (for females) and -0.20 (for females).

If we literally interpret the results, then we can conclude that a moderate level of digitalization (countries from 2nd quartile) is most favorable for HLY at birth. However, the tools and depth of research do not allow such a conclusion. Rather, the results obtained cast doubt on the unconditional effectiveness of digitalization from the standpoint of the life of an individual. Therefore, there is great potential for increasing HLY at birth. This is especially true for countries that are on decades behind the leaders in this indicator.

Conclusion. In the EU-28 member states, the process of digitalization and the construction of the Digital Single Market are actively underway. Its positive results are recorded in the continuous growth of DESI. However, against the background of these processes, a steady increase in HLY at birth is not observed.

The digitalization leader countries not only do not show high levels of HLY at birth, but also can not to reduce their gap with the countries of the leaders on HLY. For most of the EU-28 countries, with a deep digitalization level, a decrease in HLY is observed. This is a very unexpected result.

Thus, the hypothesis that "countries with a higher level of digitalization will be able to provide higher HLY for their citizens and its positive dynamics" has not been confirmed. No positive effect was found. 


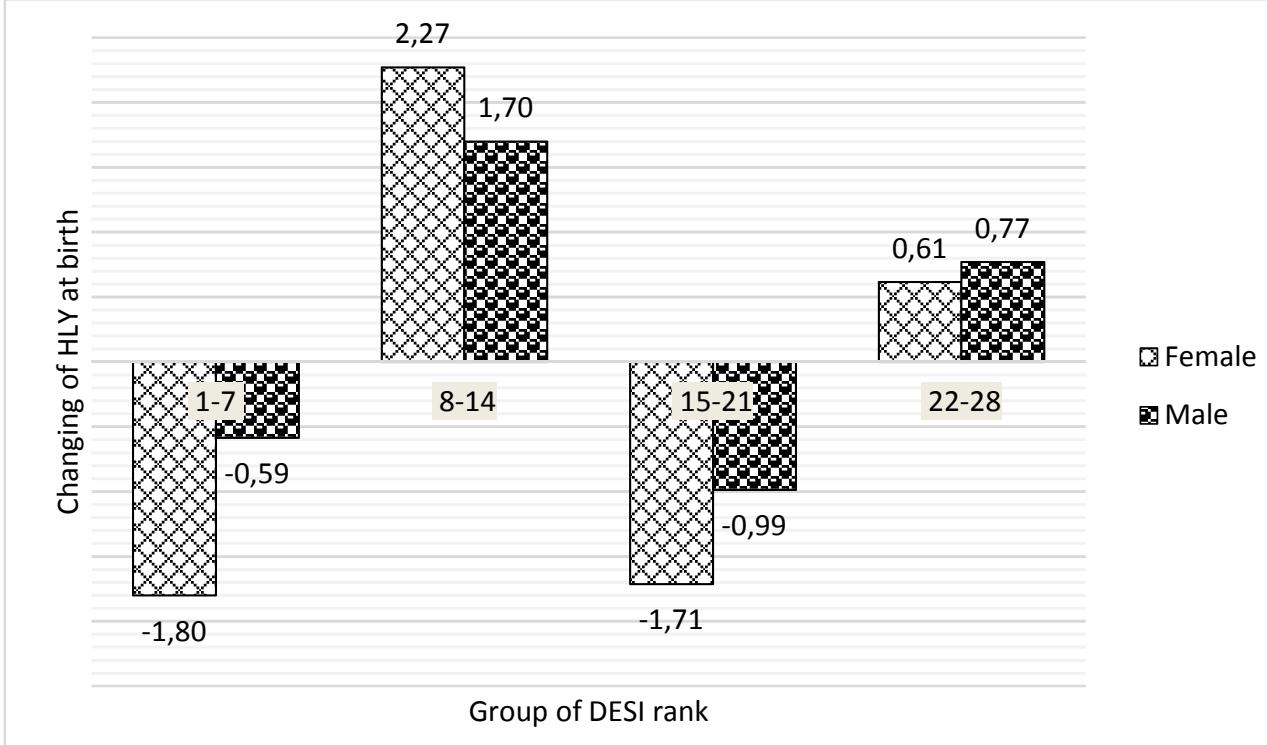

Fig. 2. HLY at birth in DESI quarters

Directions for further research. The directions of further research are related to the consideration of changes in the duration and quality of life depending on the level of digitalization in other parts of the world, as well as their compare with each other.

An important issue for the study is the analysis and systematization of the reasons for the lack of a positive impact of the digitalization level on HLY in the EU countries. As well as it's necessary the development of organizational, institutional, economic, technological tools for the effective use of the potential of digitalization in order to increase HLY.

\section{Literature}

1. Ляшенко В.І., Вишневський О.С. Цифрова модернізація економіки України як можливість проривного розвитку. Київ: Ін-т економіки пром-сті НАН України, 2018. 252 с. 2. Vyshnevskyi O. (2019). Unity of digital and virtual economies within concept of dataism. Virtual Economics. 2(3), 7-21. https://doi.org/10.34021/ ve.2019.02.03(1). 3. Іванов С.В., Вишневський О.С. Электронные платформы как инструмент модернизации экономики Украины. Вісник економічної науки України. 2017. № 1 (32). С. 47-53. 4. Gault F. (2019) User Innovation in the Digital Economy. Foresight and STI Governance, vol. 13, no 3, pp. 6-12. doi: 10.17323/ 25002597 .2019.3.6.12. 5. Shuaib K., Saleous H., Shuaib K., \& Zaki N. (2019). Blockchains for Secure Digitized Medicine. Jornal of Personalized Medicine. 9:35; p.1-21. doi:10.3390/jpm9030035. 6. Перелет Р.А. Экологические аспекты цифровой экономики. Экономика XXI века. 2018. №4. С.39-45. doi: 10.26794/2220-6469-201812-4-39-45. 7. Вишневский А.С. Оценка социальной ориентации экономики в контексте государственной региональной политики Украины. Ars Administrandi (Искусство управления). 2013. № 3. С. 58-74. 8. Robine J.-M., et al. (2013). The joint action on healthy life years (JA: EHLEIS). Archives of Public Health, 71:2. doi:10.1186/0778-7367-71-2. 9. Bogaert P. et al. (2018). The use of the global activity limitation Indicator and healthy life years by member states and the European Commission. Archives of Public Health 76:30. URL: https://doi.org/10.1186/s13690-018-0279-z. 10. Trzpiot G., Orwat-Acedańska A. (2016). Spatial Quantile Regression In Analysis Of Healthy Life Years In The European Union Countries. Comparative Economic Research, Volume 19, Number 5, 2016. doi: 10.1515/cer2016-0044. 11. A Digital Agenda for Europe. (2010). European Commission. COM/2010/0245 final. Brussels. URL: https://eur-lex.europa.eu/legal-content/en/ALL/?uri $=$ CELEX\%3A52010DC0245. 12. A Digital Single Market Strategy for Europe. (2015). European Commission. COM/2015/0192 final. URL: https://eur-lex. europa.eu/legal-content/EN/TXT/?uri=celex\%3A52015D C0192. 13. Building a European Data Economy. (2017). European Commission. COM/2017/09 final. URL: https://eur-lex.europa.eu/legal-content/EN/TXT/?qid=152 1790097276\&uri=CELEX:52017DC0009. 14. Folea, V. (2018). European public policies in the area of the digital economy and society: country performance analysis. $\mathrm{CBU}$ international conference on innovations in science and education. March 21-23, Prague, Czech Republic. P.120128. 15. Measuring the Information Society Report 2018. (2018). International Telecommunication Union. Volume 1. URL: https://www.itu.int/en/ITU-D/Statistics/ Documents/publications/misr2018/MISR-2018-Vol-1-E. pdf. 16. Digital Adoption Index. (2016). The World Bank. Washington. URL: https://www.worldbank.org/en/publi cation/wdr2016/Digital-Adoption-Index. 17. Digital Economy and Society Index (DESI) 2019 ranking. (2019). European Commission. Brussels. URL: https: //ec.europa. eu/digital-single-market/en/digital-economy-and-societyindex-desi. 18. IMD Digital Competitiveness Ranking 2019. (2019). IMD World Competitiveness Center. URL: https://www.imd.org/wcc/world-competitiveness-centerrankings/world-digital-competitiveness-rankings-2019/.

19. Enabling Digitalization Index: Beyond potential. 
(2019). Euler Hermes. Paris-La-Defense. URL: https: //www.eulerhermes.com/en_global/economic-research/in sights/2019Enabling-digitalization-index-beyond-potenti al.html. 20. Digital country index. (2017). Bloom Consulting. URL: https://www.digitalcountryindex.com/ country-index-results. 21. Miller, H., \& Stirling, R. (2019). Government Artificial Intelligence Readiness Index 2019. Oxford Insights and the International Development Research Centre. URL: https://www.oxford insights.com/ai-readiness2019? fbclid=IwAR13O6KCy MvuhmlSWnQsaGY5KrfAUJ08VYF13NPRyQ4L5f297V B1OeirVo. 22. Baller, S., Dutta, S., Lanvin, B. (2016). Networked Readiness Index. The Global Information Technology Report 2016: Innovating in the Digital Economy. URL:_https://www.wsj.com/public/resources/ documents/GITR2016.pdf. 23. Milošević, N., Dobrota, M., Rakočević, S. (2018). Digital economy in Europe: Evaluation of countries' performances. Zb. rad. Ekon. fak. Rij. vol. 36. No. 2. P. 861-880. doi:10.18045/ZBEFRI. 2018.2.861. 24. Healthy life years and life expectancy at birth, by sex. (2019). Eurostat. URL: https://ec.europa.eu/ eurostat $/$ tgm/refreshTableAction.do?tab=table\&plugin=1 $\&$ pcode $=$ tps $00150 \&$ language $=$ en .

\section{References}

1. Lyashenko V.I. \& Vyshnevskyi O.S. (2018). Digital modernization of the Ukrainian economy as an opportunity for breakthrough development. Kyiv: Institute of the Economy of Industry of the NAS of Ukraine [in Ukrainian].

2. Vyshnevskyi O. (2019). Unity of digital and virtual economies within concept of dataism. Virtual Economics, 2(3), 7-21. https://doi.org/10.34021/ve.2019. 02.03(1).

3. Ivanov S.V. \& Vyshnevskyi O.S. (2017). Electronic platforms as a tool for modernizing the Ukrainian economy. Herald of the economic sciences of Ukraine, 1 (32), pp. 47-53 [in Russian].

4. Gault F. (2019) User Innovation in the Digital Economy. Foresight and STI Governance, vol. 13, no 3, pp. 6-12. DOI: 10.17323/ 2500-2597 .2019.3.6.12.

5. Shuaib K., Saleous H., Shuaib K., \& Zaki N. (2019). Blockchains for Secure Digitized Medicine. Jornal of Personalized Medicine. 2019, 9, 35; p.1-21. doi: 10.3390/jpm9030035.

6. Perelet R. A. (2018). Environmental issues in a digital economy. World of the new economy. 12(4), 39-45. DOI: 10.26794/2220-6469-2018-12-4-39-45 [in Russian].

7. Vyshnevsky A.S. (2013). Assessment of the social orientation of the economy in the context of the state regional policy of Ukraine. Ars Administrandi, Vol. 3, pp. 58-74 [in Russian].

8. Robine J.-M., et al. (2013). The joint action on healthy life years (JA: EHLEIS). Archives of Public Health, 71:2. doi:10.1186/0778-7367-71-2

9. Bogaert P. et al. (2018). The use of the global activity limitation Indicator and healthy life years by member states and the European Commission. Archives of Public Health, 76:30. https://doi.org/10.1186/s13690-0180279-z.
10. Trzpiot G., Orwat-Acedańska A. (2016) Spatial Quantile Regression In Analysis Of Healthy Life Years In The European Union Countries. Comparative Economic Research, Vol. 19, No 5. doi:10.1515/cer-2016-0044.

11. A Digital Agenda for Europe. (2010). European Commission. COM/2010/0245 final. Brussels. Retrieved from https://eur-lex.europa.eu/legal-content/en/ALL/?uri= CELEX\%3A52010DC0245.

12. A Digital Single Market Strategy for Europe. (2015). European Commission. COM/2015/0192 final. Retrieved from https://eur-lex.europa.eu/legal-content/EN/ TXT/?uri=celex\%3A52015DC0192.

13. Building a European Data Economy. (2017). European Commission. COM/2017/09 final. Retrieved from https://eur-lex.europa.eu/legal-content/EN/TXT/? qid=1521790097276\&uri=CELEX:52017DC0009.

14. Folea V. (2018). European public policies in the area of the digital economy and society: country performance analysis. $C B U$ international conference on innovations in science and education. March 21-23, 2018, Prague, Czech Republic. P.120-128.

15. Measuring the Information Society Report 2018. (2018). International Telecommunication Union. Vol. 1. Retrieved from https://www.itu.int/en/ITU-D/Statistics/ Documents/publications/misr2018/MISR-2018-Vol-1-E. pdf.

16. Digital Adoption Index. (2016). The World Bank. Washington. Retrieved from https://www.worldbank.org/ en/publication/wdr2016/Digital-Adoption-Index.

17. Digital Economy and Society Index (DESI) 2019 ranking. (2019). European Commission. Brussels. Retrieved from https://ec.europa.eu/digital-single-market/ en/digital-economy-and-society-index-desi.

18. IMD Digital Competitiveness Ranking 2019. (2019). IMD World Competitiveness Center. Retrieved from https://www.imd.org/wcc/world-competitivenesscenter-rankings/world-digital-competitiveness-rankings$2019 /$.

19. Enabling Digitalization Index: Beyond potential. (2019). Euler Hermes. Paris-La-Defense. Retrieved from https://www.eulerhermes.com/en_global/economic-resear ch/insights/2019Enabling-digitalization-index-beyond-po tential.html.

20. Digital country index. Bloom Consulting. Retrieved from https://www.digitalcountryindex.com/ country-index-results.

21. Miller H. \& Stirling R. (2019). Government Artificial Intelligence Readiness Index 2019. Oxford Insights and the International Development Research Centre. Retrieved from https:/www.oxfordinsights.com/ ai-readiness2019?fbclid=IwAR13O6KCy_MvuhmlSWn QsaGY5KrfAUJ08VYF13NPRyQ4L5f297VB1OeirVo.

22. Baller S., Dutta S., Lanvin B. (2016). Networked Readiness Index. The Global Information Technology Report 2016: Innovating in the Digital Economy. Retrieved from https:/www.wsj.com/public/resources/ documents/GITR2016.pdf .

23. Milošević, N., Dobrota, M., Rakočević, S. (2018). Digital economy in Europe: Evaluation of countries' 
performances. Zb. rad. Ekon. fak. Rij. vol. 36. No. 2. P. 861-880. doi:10.18045/ZBEFRI.2018.2.861.

24. Healthy life years and life expectancy at birth, by sex. (2019). Eurostat. Retrieved from_https://ec.europa.eu/ eurostat $/ \operatorname{tgm} /$ refreshTableAction.do?tab=table\&plugin $=1$ $\&$ pcode $=$ tps $00150 \&$ language $=$ en.

Вишневський О. С. Оцінка показника «Роки здорового життя» в умовах цифровізації СС

У роботі розглядається оцінка впливу цифровізації на людину. Аналіз літератури показав, що залишається недостатньо дослідженою проблема впливу цифровізації на кількість років здорового життя. Як об'єкт дослідження обрані країни-члени СС-28, оскільки, 3 одного боку, в ЄС входять суверенні держави, а 3 іншого - це єдиний ринок праці і капіталу. При цьому в ЄС активно підтримуються процеси цифровізації на законодавчому рівні та виконується робота 3 побудови єдиного цифрового ринку. Виходячи з огляду літературних джерел і об'єкта дослідження метою дослідження є оцінка стану і динаміки «здорових років життя» в умовах цифровізації в країнах $\mathrm{CC}$.

Основні результати. Країни-лідери по цифровізації не тільки не демонструють високих рівнів за кількістю «здорових років життя», а й не можуть скоротити своє відставання від країн лідерів за показником «роки здорового життя». Таким чином, гіпотеза, що «країни з більш високим рівнем цифровізації зможуть забезпечити більшу кількість «здорових років життя» для своїх громадян і їх позитивну динаміку» не підтвердилася. Позитивний вплив не виявлено.

Ключові слова: цифровізація, показник «Роки здорового життя», ЄС.

Vyshnevskyi O. Evaluation of the Healthy Life Years Indicator in Conditions of EU Digitalization

The paper considers the impact of digitalization on humans. An analysis of the literature showed that the problem of the impact of digitalization on the number of years of a healthy life remains insufficiently studied. As an object of study, the EU-28 member countries were selected. Since, on the one hand, the EU includes sovereign states, and on the other, it is a single labor and capital market. At the same time, the process of digitalization at the legislative level is actively supported in the EU and work is underway to build a Digital Single Market. Based on a review of literary sources and the object of study, the aim of the study is to assess the status and dynamics of "Healthy Life Years" in the context of digitalization in the EU countries.

The main results. The countries leaders in digitalization not only do not show high levels in terms of the number of "Healthy Life Years", but I can't reduce their back$\log$ from the countries of the leaders in terms of Healthy Life Years". Thus, the hypothesis that "countries with a higher level of digitalization will be able to provide a greater number of "Healthy Life Years" for their citizens and its positive dynamics" has not been confirmed. No positive effect was found.

Keywords: digitalization, Healthy Life Years indicator, EU.

Вишневский А. С. Оценка показателя «Годы здоровой жизни» в условиях цифровизации ЕС

В работе рассматривается оценка влияния цифровизации на человека. Анализ литературы показал, что остаётся недостаточно исследованной проблема влияния цифровизации на количество лет здоровой жизни. В качестве объекта исследования выбраны странычлены ЕС-28, так как, с одной стороны, в ЕС входят суверенные государства, а с другой - это единый рынок труда и капитала. При этом в ЕС активно поддерживаются процессы цифровизации на законодательном уровне и проделывается работа по построению единого цифрового рынка. Исходя из обзора литературных источников и объекта исследования, целью исследования является оценка состояния и динамики «здоровых лет жизни» в условиях цифровизации в странах ЕС.

Основные результаты. Страны лидеры по цифровизации не только не демонстрируют высоких уровней по количеству «здоровых лет жизни», но и не могут сократить своё отставания от стран лидеров по показателю «годы здоровой жизни». Таким образом, гипотеза, что «страны с более высоким уровнем цифровизации смогут обеспечить большее количество «здоровых лет жизни» для своих граждан и их позитивную динамику» не подтвердилась. Позитивное влияние не обнаружено.

Ключевые слова: цифровизация, показатель «Годы здоровой жизни», ЕС.

Received by the editors: 09.12.2019

and final form 19.12.2019 